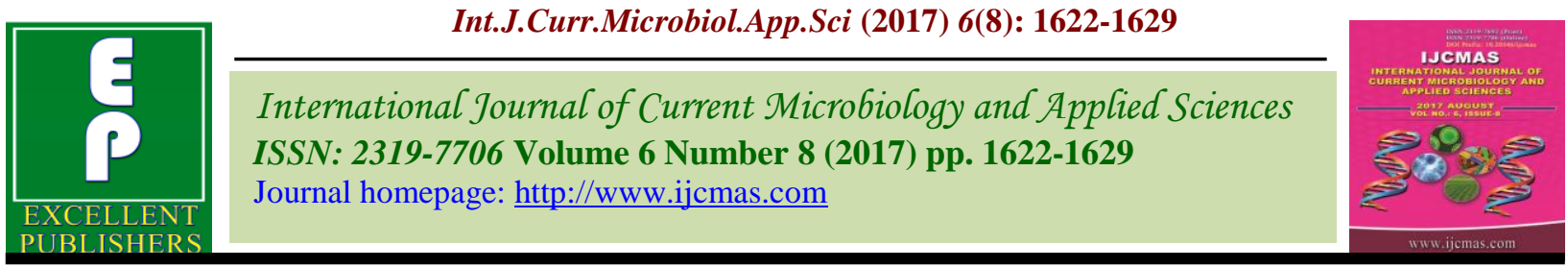

Original Research Article

https://doi.org/10.20546/ijcmas.2017.608.195

\title{
Paclobutrazol in Improving Productivity and Quality of Litchi
}

\author{
Sonam Ongmu Bhutia*, Aditi Guha Choudhury and Md. Abu Hasan \\ Department of Fruits and Orchard Management, Faculty of Horticulture \\ Bidhan Chandra Krishi Viswavidyalaya, West Bengal-741252, India \\ *Corresponding author
}

\section{A B S T R A C T}

For sustenance in litchi production effect of soil application of paclobutrazol in cv. Bombai was investigated over two years, 2013-14 and 2014-15 during autumn winter

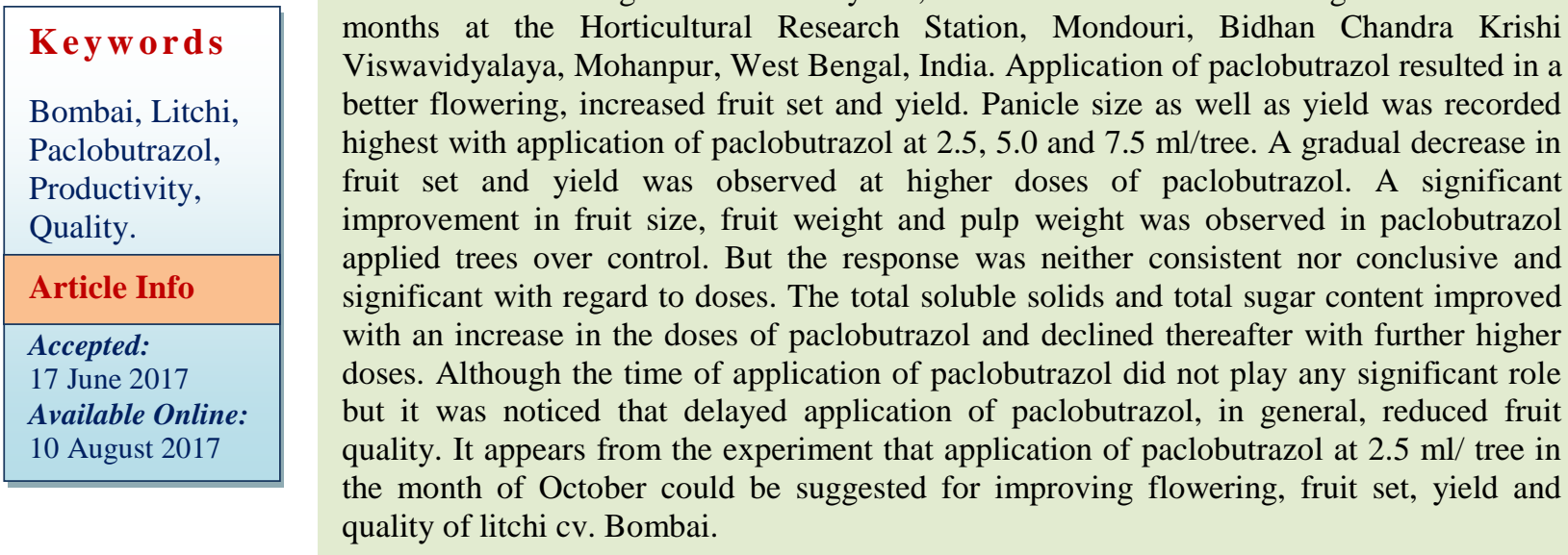

\section{Introduction}

The queen of fruit crop litchi (Litchi chinensis Sonn.) is a subtropical fruit that belongs to the family Sapindaceae and considered to be very delicious for its excellent quality, high nutritive and medicinal values, characteristic pleasant flavour and attractive red colour that bring litchi fruits popularity in the Indian and foreign markets (Revathy and Narasimham, 1997 and Kumar, 1998). In the production side, the major problem is low and irregular bearing, which is preventing litchi from becoming the major crop of subtropical region so far (Pandey and Sharma, 1989). The problem is generally due to failure of flower initiation, which put fourth vegetative growth 1-2 months prior to the panicle emergence and flowering, eliminating the crop completely. Vegetative or delayed flushing during autumn and erratic winter leads to physiological immaturity of the shoots that results the irregular bearing in litchi (Nagao et al., 2000). Beside low yields due to irregular bearing, poor flowering and fruit set al., so hinder the litchi production.

Temperature, moisture, photoperiod, nutrition, bio regulators and some cultural practices are suspected to be responsible for 
transformation of vegetative bud to a reproductive bud. Exogenous application of some growth regulators had shown effective results to regulate the growth pattern and yield of litchi such as, paclobutrazol, a gibberellin biosynthesis inhibitor, showed a positive response (Ghosh et al., 1986 and Mitra et al., 2001). It has been reported to transfer a vegetative bud to a reproductive bud, profuse flowering, higher sex ratio and increased fruit set in paclobutrazol applied trees contributed to higher fruit yields in litchi has also been supported by Oosthuizen et al., (1995) and Ahmed et al., (2000).

But value of fruit crops not only depends upon the yield; quality production is one of the most important factors that determine market demand. Chemicals that are used to induce flowering should not hamper fruit quality anyway rather it should have a positive impact on the ultimate produce. Hence in this relevant context the present research was undertaken to study the effect of paclobutrazol on flowering as well as fruit characteristics of litchi cultivar 'Bombai' in the Gangetic alluvial region of West Bengal, India.

\section{Materials and Methods}

\section{Experimental site}

The present experiment was carried out at the Horticultural Research Station of Bidhan Chandra Krishi Viswavidyalaya, located at Mondouri, Nadia, West Bengal, during September to May of 2013-14 and 2014-15. The location of the experimental site is $23.5^{\circ}$ North latitude and $80^{\circ}$ East longitude and at an altitude of $9.75 \mathrm{~m}$ from the mean sea level. The experimental site was on a high land with assured irrigation as well as good drainage facilities. The soil of the experimental site is Gangetic Alluvial (Entisol) with sandy clayloam texture having good water holding capacity and medium soil fertility status. The climatic condition of experimental site is subtropical sub-humid.

\section{Experimental details}

For both the years (2013-14 and 2014-15), paclobutrazol was applied to litchi cv. Bombai at $1^{\text {st }}$ week of 4 consecutive months i.e., September $\left(\mathrm{M}_{1}\right)$, October $\left(\mathrm{M}_{2}\right)$, November $\left(\mathrm{M}_{3}\right)$ and December $\left(\mathrm{M}_{4}\right)$. In each month it was applied in 8 different doses at the rates of $2.5 \mathrm{ml} /$ tree $\left(\mathrm{A}_{1}\right), 5 \mathrm{ml} /$ tree $\left(\mathrm{A}_{2}\right)$, $7.5 \mathrm{ml} /$ tree $\left(\mathrm{A}_{3}\right), 10 \mathrm{ml} /$ tree $\left(\mathrm{A}_{4}\right), 12.5 \mathrm{ml} /$ tree $\left(\mathrm{A}_{5}\right), 15 \mathrm{ml} /$ tree $\left(\mathrm{A}_{6}\right), 17.5 \mathrm{ml} /$ tree $\left(\mathrm{A}_{7}\right)$, $20 \mathrm{ml} /$ tree $\left(\mathrm{A}_{8}\right)$ and control $\left(\mathrm{A}_{9}\right)$. A ring approximately of $50 \mathrm{~cm}$ width was made under each tree inside the drip line and the required doses of paclobutrazol were dissolved in 10 litre of water and were uniformly applied to the ring except for control where no paclobutrazol treatment was given. The ring was then covered with soil.

\section{Observations recorded}

Different floral and fruit characters like length of panicle, width of panicle, number of fruit set/ panicle, number of fruit/ tree, fruit weight, length of fruit, width of fruit, weight of pulp, aril thickness, weight of stone, length of stone, width of stone, weight of peel, pulppeel-stone percentage, total soluble solids, sugars (total, reducing and non-reducing), vitamin-C, total titratable acidity were recorded.

\section{Statistical analysis}

Analysis of variance (Two way classified data) for each parameter was performed using OPSTAT software (Online version).The statistical analysis was done by factorial RBD (Randomized block design) with three replication and one factor as doses of paclobutrazol and another factor as different 
months of paclobutrazol application was followed. Any main effect either due to dose or month if significantly higher, it means that combination is a performing one if and only if the higher magnitude is demanded, otherwise the reverse is accepted. The significance of different sources of variation was tested by error mean square by Fischer-Snedecor's ' $F$ ' test at probability level of 0.05 percent.

\section{Results and Discussion}

Table 1 showed that, the maximum panicle length $(34.85 \mathrm{~cm})$ was recorded with the application of paclobutrazol at $2.5 \mathrm{ml} /$ tree. On the other hand, the maximum panicle diameter $(10.59 \mathrm{~cm})$ was recorded with the application of paclobutrazol at $5 \mathrm{ml} /$ tree. However, panicle length did vary significantly due to the application of the chemical at 2.5- $15 \mathrm{ml} /$ tree. Application of $15-20 \mathrm{ml} /$ tree of paclobutrazol/ tree decreased panicle length significantly. Chaitrakulsub et al., (1992) confirmed that panicle size decreased with an increase in the dose of paclobutrazol.

It is confirmed that number of fruit/ panicle was recorded maximum (40.10 number of fruits/ panicle) with application of paclobutrazol at $2.5 \mathrm{ml} /$ tree which is at par with $5 \mathrm{ml}$ of paclobutrazol/ tree (40.06 number of fruits/ panicle) as compared to control (38.60 fruits/ panicle). Pires and Yamanishi (2014) confirmed that the average number of fruits per inflorescence in trunk girdled and treated with paclobutrazol at a dose of $1.0 \mathrm{~g}$ of a.i./ linear meter of canopy, was significantly higher than in the control trees. Application of paclobutrazol at different time did have significant effect on number of fruit set per panicle. Number of fruits per tree and yield (tonne/ ha) were recorded highest (4158.49 number/ tree and 7.89 tonne/ ha) with paclobutrazol application at $2.5 \mathrm{ml} /$ tree followed by paclobutrazol application at $5 \mathrm{ml} /$ tree (4059.98 number/ tree and 7.71 tonne/ ha). The time of application of chemical had no significant effect on number of fruits per tree and yield per tree.

The highest fruit weight (20.20 g) and pulp weight $(13.13 \mathrm{~g})$ were recorded with $12.5 \mathrm{ml} /$ tree dose of paclobutrazol whereas, lowest were recorded with control both for fruit $(18.89 \mathrm{~g})$ and pulp (12.01 g) weight. Highest fruit weight $(19.83 \mathrm{~g})$ was recorded with the application of paclobutrazol in the month of November (Table 1). Paclobutrazol generally had only a small effect on average fruit weight (Menzel and Simpson, 1990). The highest stone weight $(4.02 \mathrm{~g})$ was recorded with $2.5 \mathrm{ml}$ and followed by $5 \mathrm{ml}$ of paclobutrazol per tree $(3.90 \mathrm{~g})$. An increase in stone weight was recorded with delayed application of paclobutrazol from September to December without any significant variation (Table 1). No much significant variation in peel weight was observed with different doses of paclobutrazol except with $10 \mathrm{ml}$ of paclobutrazol per tree $(3.74 \mathrm{~g})$. In contrast, early application of paclobutrazol in the month of September and October showed highest peel weight which was statistically at par and with a gradual reduction with application in the month of November and onwards.

The highest fruit length $(3.87 \mathrm{~cm})$ recorded with $2.5 \mathrm{ml}$ of paclobutrazol per tree, whereas, the minimum fruit length $(3.36 \mathrm{~cm})$ was noted with control. The effect of different dose and time of paclobutrazol did not produce much significant variation on fruit diameter. The highest stone length was recorded with $12.5 \mathrm{ml}$ of paclobutrazol per tree, whereas, the highest stone diameter was recorded with control. There was no much difference with the application of paclobutrazol from September to December which was statistically at par. 
The effect of different dose with regards to aril thickness (Table 2) was recorded highest with $17.5 \mathrm{ml} /$ tree $(0.78 \mathrm{~cm})$ followed by $20 \mathrm{ml} /$ tree $(0.73 \mathrm{~cm})$ of paclobutrazol and lowest $(0.61 \mathrm{~cm})$ with $7.5 \mathrm{ml} /$ tree but on the other hand time of paclobutrazol did not produce any significant variation on aril thickness. Menzel and Simpson (1990) reported that the effect of paclobutrazol on the proportion of aril was small and variable.

The highest pulp per cent (66.29 per cent), peel per cent were recorded in $10 \mathrm{ml}$ and 17.5 $\mathrm{ml} /$ tree of paclobutrazol per tree. Minimum pulp per cent (62.78 per cent) was noted in $2.5 \mathrm{ml} /$ tree of paclobutrazol. In general an increase in pulp per cent was recorded with the application of different doses of paclobutrazol. There was no much significant variation in pulp percentage and peel percentage due to different time of application. The highest stone content (19.77 per cent) was recorded with $2.5 \mathrm{ml} /$ tree of paclobutrazol at par with other treatment except $10 \mathrm{ml}$ and $17.5 \mathrm{ml} /$ tree of paclobutrazol (Table 2). However, an application of paclobutrazol from September to December did not show much significant variation in stone content.

Highest total soluble solid content $\left(17.85^{\circ}\right.$ brix), total sugar (16.38 per cent), reducing sugar (9.25 per cent) and non- reducing sugar (6.22 per cent) were obtained from $10 \mathrm{ml}, 7.5$ $\mathrm{ml}, 10 \mathrm{ml}$ and $20 \mathrm{ml}$ paclobutrazol per tree respectively (Table 3). However, the effect of time of application of paclobutrazol was shown highest in October application for both total soluble solids and total sugar, but on the other hand for reducing sugar in September application and whereas, for non- reducing sugar it did not show any significant variation. Results of present study were corroborated by the findings of Singh, 1996 in litchi. All the treatments helped in producing more TSS than in fruits under control (Table
3). The increase in total soluble solids were might be due to the metabolizing effect of growth retardants and their effect on osmotic pressure of the cells tends to increase and solutes like ions and sugars accumulates and thus the TSS level was increased in treated fruits. Ahmed et al., (2000) reported that other reason may be increased efficiency of photosynthetic apparatus (leaves) of paclobutrazol treated plants resulting in increase content of TSS in litchi fruits.

The lowest acidity content 0.29 per cent was recorded with $5 \mathrm{ml}$ of paclobutrazol per tree and highest with 0.48 per cent $10 \mathrm{ml}$ of paclobutrazol per tree. There was no significant variation in acid content of fruit due to different time of paclobutrazol application. Rani and Brahmachari (2000) made similar observations that paclobutrazol produced high acidity due to the accumulation of organic acids in the fruit sac.

The highest TSS: acidity ratio (59.08) was recorded with the $5 \mathrm{ml} /$ tree of paclobutrazol as compared to the lowest (39.09) under control. But, the time of application of paclobutrazol failed to bring any significant variation in TSS: acidity ratio. Pires and Yamanishi (2014) confirmed that maximum TSS/acid ratio was noticed in 2000 ppm cycocel and minimum in control.

The highest Vitamin C content $(85 \mathrm{mg} / 100 \mathrm{~g}$ of pulp) was recorded with $2.5 \mathrm{ml} /$ tree of paclobutrazol as compared to minimum (69.69 mg/ $100 \mathrm{~g}$ of pulp) under control. The maximum Vitamin C (76.78 mg/ $100 \mathrm{~g}$ of pulp) was recorded with the application in the month of October (Table 3 ).

From the above experiment, it can be concluded that the application of higher doses of paclobutrazol did not show much of good response in terms of fruit set, yield and quality. 
Table.1 Effect of different doses and time of paclobutrazol application on panicle length, panicle diameter, fruit set, no. of fruits/ tree, yield, fruit weight, pulp weight and stone weight of litchi fruit

\begin{tabular}{|c|c|c|c|c|c|c|c|c|}
\hline Treatment & $\begin{array}{c}\text { Panicle } \\
\text { length } \\
\text { (cm) }\end{array}$ & $\begin{array}{c}\text { Panicle } \\
\text { diameter }(\mathbf{c m})\end{array}$ & $\begin{array}{c}\text { Fruit set } \\
\text { (No./ } \\
\text { panicle) }\end{array}$ & $\begin{array}{c}\text { No. of } \\
\text { fruits/ } \\
\text { tree }\end{array}$ & $\begin{array}{c}\text { Yield } \\
\text { (tonne/ ha) }\end{array}$ & $\begin{array}{c}\text { Fruit } \\
\text { weight }(\mathrm{g})\end{array}$ & $\begin{array}{c}\text { Pulp } \\
\text { weight (g) }\end{array}$ & $\begin{array}{c}\text { Stone } \\
\text { weight }(g)\end{array}$ \\
\hline \multicolumn{9}{|l|}{$\begin{array}{l}\text { Paclobutrazol } \\
\text { dose (ml/tree) }\end{array}$} \\
\hline $\mathbf{A}_{1}$ & 34.85 & 10.14 & 40.10 & 4158.49 & 7.89 & 19.32 & 12.01 & 4.02 \\
\hline $\mathbf{A}_{2}$ & 33.24 & 10.59 & 40.06 & 4059.98 & 7.71 & 19.97 & 13.12 & 3.90 \\
\hline $\mathbf{A} 3$ & 32.16 & 9.66 & 38.47 & 3868.81 & 7.74 & 19.92 & 12.71 & 3.78 \\
\hline $\mathbf{A}_{4}$ & 33.97 & 9.61 & 37.0 & 3731.89 & 7.18 & 19.91 & 13.07 & 3.28 \\
\hline $\mathbf{A}_{5}$ & 32.68 & 9.77 & 38.01 & 3802.47 & 7.30 & 20.20 & 13.13 & 3.81 \\
\hline $\mathbf{A}_{6}$ & 29.01 & 9.52 & 36.96 & 3695.59 & 7.20 & 19.80 & 12.98 & 3.76 \\
\hline $\mathbf{A}_{7}$ & 27.41 & 9.68 & 37.96 & 3743.78 & 7.11 & 19.23 & 12.06 & 3.37 \\
\hline $\mathbf{A}_{8}$ & 26.45 & 9.71 & 36.72 & 3396.31 & 6.51 & 20.02 & 13.01 & 3.20 \\
\hline $\mathbf{A}_{9}$ & 32.31 & 10.16 & 38.60 & 3751.37 & 7.22 & 18.89 & 12.01 & 3.06 \\
\hline CD at $5 \%$ & 0.48 & 0.15 & 0.52 & 58.39 & 0.12 & 0.32 & 0.21 & 0.07 \\
\hline $\operatorname{S~Em~}( \pm)$ & 0.24 & 0.07 & 0.19 & 20.66 & 0.04 & 0.11 & 0.07 & 0.02 \\
\hline \multicolumn{9}{|l|}{$\begin{array}{c}\text { Time of } \\
\text { application } \\
\text { (month) }\end{array}$} \\
\hline $\mathbf{M}_{1}$ & 31.34 & 9.97 & 38.36 & 3796.78 & 7.31 & 19.71 & 12.66 & 3.58 \\
\hline $\mathbf{M}_{2}$ & 31.68 & 10.05 & 38.74 & 3834.56 & 7.38 & 19.55 & 12.76 & 3.57 \\
\hline $\mathbf{M}_{3}$ & 31.21 & 9.91 & 38.01 & 3776.02 & 7.25 & 19.83 & 12.51 & 3.56 \\
\hline $\mathbf{M}_{4}$ & 31.14 & 9.82 & 38.43 & 3796.50 & 7.34 & 19.70 & 12.77 & 3.59 \\
\hline CD at 5\% & 0.32 & 0.09 & 0.35 & 38.93 & 0.08 & N/A & 0.14 & N/A \\
\hline $\operatorname{SEm}( \pm)$ & 0.15 & 0.05 & 0.12 & 13.77 & 0.03 & 0.08 & 0.05 & 0.02 \\
\hline
\end{tabular}

$\mathrm{A}_{1}=$ Paclobutrazol @ 2.5ml/tree, $\mathrm{A}_{2}=$ Paclobutrazol @ 5ml/tree, $\mathrm{A}_{3}=$ Paclobutrazol @7.5ml/tree,

$\mathrm{A}_{4}=$ Paclobutrazol @ 10ml/tree, $\mathrm{A}_{5}=$ Paclobutrazol @ 12.5ml/tree, $\mathrm{A}_{6}=$ Paclobutrazol @ 15ml/tree,

$\mathrm{A}_{7}=$ Paclobutrazol @ 17.5ml/tree, $\mathrm{A}_{8}=$ Paclobutrazol @20 $\mathrm{ml} /$ tree and $\mathrm{A}_{9}=$ Control

$\mathrm{M}_{1}=$ September, $\mathrm{M}_{2}=$ October, $\mathrm{M}_{3}=$ November, $\mathrm{M}_{4}=$ December. 
Table.2 Effect of different doses and time of paclobutrazol application on peel weight, fruit diameter, fruit length, stone length, stone diameter, aril thickness, pulp per cent and stone per cent of litchi fruit

\begin{tabular}{|c|c|c|c|c|c|c|c|c|}
\hline Treatment & $\begin{array}{c}\text { Peel weight } \\
\text { (g) }\end{array}$ & $\begin{array}{c}\text { Fruit } \\
\text { diameter } \\
(\mathrm{cm})\end{array}$ & $\begin{array}{c}\text { Fruit } \\
\text { length }(\mathrm{cm})\end{array}$ & $\begin{array}{l}\text { Stone } \\
\text { length } \\
(\mathrm{cm})\end{array}$ & $\begin{array}{c}\text { Stone } \\
\text { diameter } \\
(\mathrm{cm})\end{array}$ & $\begin{array}{c}\text { Aril } \\
\text { Thickness } \\
(\mathbf{c m})\end{array}$ & $\begin{array}{l}\text { Pulp (per } \\
\text { cent) }\end{array}$ & $\begin{array}{l}\text { Stone (per } \\
\text { cent) }\end{array}$ \\
\hline \multicolumn{9}{|l|}{$\begin{array}{l}\text { Paclobutrazol } \\
\text { dose (ml/tree) }\end{array}$} \\
\hline $\mathbf{A}_{1}$ & 3.41 & 3.87 & 3.30 & 2.93 & 1.32 & 0.71 & 62.78 & 19.77 \\
\hline $\mathbf{A}_{2}$ & 2.88 & 3.69 & 3.09 & 2.79 & 1.30 & 0.63 & 65.49 & 19.42 \\
\hline $\mathbf{A}_{3}$ & 3.29 & 3.73 & 3.05 & 2.70 & 1.36 & 0.61 & 63.56 & 19.36 \\
\hline $\mathbf{A}_{4}$ & 3.74 & 3.73 & 2.99 & 2.75 & 1.30 & 0.71 & 64.72 & 16.70 \\
\hline $\mathbf{A}_{5}$ & 3.32 & 3.81 & 3.07 & 3.37 & 1.26 & 0.69 & 64.67 & 18.78 \\
\hline $\mathbf{A}_{6}$ & 2.88 & 3.65 & 3.15 & 3.09 & 1.18 & 0.69 & 66.29 & 19.03 \\
\hline $\mathbf{A}_{7}$ & 3.38 & 3.69 & 3.14 & 2.94 & 1.29 & 0.78 & 63.03 & 17.78 \\
\hline $\mathbf{A}_{8}$ & 3.19 & 3.60 & 3.14 & 3.14 & 1.19 & 0.73 & 64.38 & 18.94 \\
\hline$A_{9}$ & 3.38 & 3.36 & 3.02 & 2.92 & 1.43 & 0.72 & 63.13 & 18.90 \\
\hline CD at 5\% & 0.06 & 0.06 & 0.05 & 0.05 & 0.03 & 0.02 & 0.10 & 0.28 \\
\hline S Em ( \pm ) & 0.02 & 0.02 & 0.02 & 0.02 & 0.01 & 0.01 & 0.35 & 0.01 \\
\hline \multicolumn{9}{|l|}{$\begin{array}{c}\text { Time of } \\
\text { application } \\
\text { (month) }\end{array}$} \\
\hline $\mathbf{M}_{1}$ & 3.31 & 3.71 & 3.07 & 2.99 & 1.30 & 0.70 & 64.35 & 18.79 \\
\hline $\mathbf{M}_{2}$ & 3.33 & 3.74 & 2.97 & 3.01 & 1.31 & 0.70 & 64.87 & 18.69 \\
\hline $\mathbf{M}_{3}$ & 3.25 & 3.69 & 2.97 & 2.95 & 1.28 & 0.70 & 64.66 & 18.61 \\
\hline $\mathbf{M}_{4}$ & 3.22 & 3.58 & 3.07 & 2.90 & 1.28 & 0.70 & 64.03 & 18.88 \\
\hline CD at 5\% & 0.04 & 0.04 & 0.03 & 0.04 & 0.02 & N/A & 0.66 & 0.19 \\
\hline S Em $( \pm)$ & 0.01 & 0.02 & 0.01 & 0.01 & 0.01 & 0.01 & 0.24 & 0.07 \\
\hline
\end{tabular}

$\mathrm{A}_{1}=$ Paclobutrazol @ 2.5ml/tree, $\mathrm{A}_{2}=$ Paclobutrazol @ $5 \mathrm{ml} /$ tree, $\mathrm{A}_{3}=$ Paclobutrazol @ 7.5ml/tree,

$\mathrm{A}_{4}=$ Paclobutrazol @ 10ml/tree, $\mathrm{A}_{5}=$ Paclobutrazol @ 12.5ml/tree, $\mathrm{A}_{6}=$ Paclobutrazol @ 15ml/tree,

$\mathrm{A}_{7}=$ Paclobutrazol @ 17.5ml/tree, $\mathrm{A}_{8}=$ Paclobutrazol @20ml/tree and $\mathrm{A}_{9}=$ Control

$\mathrm{M}_{1}=$ September, $\mathrm{M}_{2}=$ October, $\mathrm{M}_{3}=$ November, $\mathrm{M}_{4}=$ December. 
Table.3 Effect of different doses and time of paclobutrazol application on peel per cent, total soluble solids, total sugar, reducing sugar, non- reducing sugar, acidity, TSS: acidity and vitamin C of litchi fruit

\begin{tabular}{|c|c|c|c|c|c|c|c|c|}
\hline Treatment & $\begin{array}{l}\text { Peel } \\
\text { (per } \\
\text { cent) }\end{array}$ & $\begin{array}{l}\text { Total soluble } \\
\text { solids ( }{ }^{\circ} \text { brix) }\end{array}$ & $\begin{array}{l}\text { Total } \\
\text { sugar } \\
\text { (per } \\
\text { cent) }\end{array}$ & $\begin{array}{l}\text { Reducing } \\
\text { sugar (per } \\
\text { cent) }\end{array}$ & $\begin{array}{l}\text { Non- reducing } \\
\text { sugar (per } \\
\text { cent) }\end{array}$ & $\begin{array}{c}\text { Acidity } \\
\text { (per cent) }\end{array}$ & $\begin{array}{c}\text { TSS: } \\
\text { acidity }\end{array}$ & $\begin{array}{c}\text { Vitamin C } \\
\text { (mg/ 100g } \\
\text { of pulp) }\end{array}$ \\
\hline \multicolumn{9}{|l|}{$\begin{array}{l}\text { Paclobutrazol } \\
\text { dose (ml/tree) }\end{array}$} \\
\hline $\mathbf{A}_{1}$ & 17.54 & 16.57 & 14.86 & 9.13 & 5.68 & 0.42 & 39.10 & 85.00 \\
\hline $\mathbf{A}_{2}$ & 16.07 & 16.78 & 14.82 & 9.14 & 5.84 & 0.29 & 59.08 & 82.24 \\
\hline $\mathbf{A} 3$ & 16.69 & 17.78 & 16.38 & 9.08 & 5.85 & 0.40 & 47.01 & 80.22 \\
\hline $\mathbf{A}_{4}$ & 18.92 & 17.85 & 16.14 & 9.25 & 5.93 & 0.48 & 40.16 & 77.85 \\
\hline $\mathbf{A}_{5}$ & 16.54 & 16.72 & 15.32 & 8.88 & 5.62 & 0.39 & 43.90 & 75.01 \\
\hline $\mathbf{A}_{6}$ & 14.46 & 16.72 & 14.86 & 9.01 & 5.97 & 0.39 & 44.78 & 72.99 \\
\hline $\mathbf{A}_{7}$ & 17.99 & 16.90 & 14.62 & 8.48 & 5.60 & 0.40 & 42.83 & 71.53 \\
\hline $\mathbf{A _ { 8 }}$ & 15.86 & 16.62 & 12.69 & 9.15 & 6.22 & 0.34 & 49.71 & 70.06 \\
\hline$A_{9}$ & 17.95 & 16.28 & 14.28 & 9.08 & 5.57 & 0.41 & 39.09 & 69.69 \\
\hline CD at $5 \%$ & 0.23 & 0.26 & 0.25 & 0.15 & 0.11 & 0.02 & 0.69 & 1.19 \\
\hline S Em ( $( \pm)$ & 0.08 & 0.09 & 0.09 & 0.05 & 0.04 & 0.01 & 0.24 & 0.42 \\
\hline \multicolumn{9}{|l|}{$\begin{array}{c}\text { Time of } \\
\text { application } \\
\text { (month) }\end{array}$} \\
\hline $\mathbf{M}_{1}$ & 16.93 & 16.97 & 14.87 & 8.96 & 5.84 & 0.39 & 45.13 & 76.13 \\
\hline $\mathbf{M}_{2}$ & 17.10 & 17.12 & 15.04 & 8.98 & 5.78 & 0.39 & 44.91 & 76.78 \\
\hline $\mathbf{M}_{3}$ & 16.76 & 16.79 & 14.79 & 9.12 & 5.81 & 0.39 & 44.84 & 75.31 \\
\hline $\mathbf{M}_{4}$ & 16.77 & 16.78 & 14.84 & 9.03 & 5.81 & 0.40 & 45.42 & 76.04 \\
\hline CD at $5 \%$ & 0.15 & 0.17 & 0.16 & 0.10 & N/A & N/A & N/A & 0.79 \\
\hline S Em ( $( \pm)$ & 0.05 & 0.06 & 0.06 & 0.04 & 0.03 & 0.00 & 0.16 & 0.28 \\
\hline
\end{tabular}

$\mathrm{A}_{1}=$ Paclobutrazol @ 2.5ml/tree, $\mathrm{A}_{2}=$ Paclobutrazol @ $5 \mathrm{ml} /$ tree, $\mathrm{A}_{3}=$ Paclobutrazol @ 7.5ml/tree,

$\mathrm{A}_{4}=$ Paclobutrazol @ 10ml/tree, $\mathrm{A}_{5}=$ Paclobutrazol @ 12.5 $\mathrm{ml} /$ tree, $\mathrm{A}_{6}=$ Paclobutrazol @ 15ml/tree,

$\mathrm{A}_{7}=$ Paclobutrazol @ 17.5ml/tree, $\mathrm{A}_{8}=$ Paclobutrazol @ 20ml/tree and $\mathrm{A}_{9}=$ Control

$\mathrm{M}_{1}=$ September, $\mathrm{M}_{2}=$ October, $\mathrm{M}_{3}=$ November, $\mathrm{M}_{4}=$ December 
From the results it can be safely regarded that the fruit set and yield of litchi cv. Bombai decreases with the application of higher doses paclobutrazol. Application of paclobutrazol at $2.5 \mathrm{ml} /$ tree in the month of October showed better results in case of fruit set, yield and quality of litchi cv. Bombai in the gangetic alluvial plains of West Bengal.

\section{References}

Ahmed, F., Ather, M. and Kumar, G. 2000. Effect of paclobutrazol on growth, yield and quality of litchi (Litchi chinensis Sonn.). Indian J. Hort., 57(4): 291-294.

Chaitrakulsub, T., Subhadrabandhu, S., Powsang, T., Ogata, R. and Gema, H. 1992. International Symp. on Tropical fruit, Frontier in Tropical Fruit Research, Pattya City, Thailand. Acta. Hort., 321: 291-299.

Ghosh, B., Bose, T.K. and Mitra, S.K. 1986. Chemical induction of flowering and control of fruit drop in litchi. Paper presented in the $22^{\text {nd }}$ Int. Hort. Cong., California, USA. Hort. Sci., 21(3): 822.

Kumar, G. 1998. Major constraints in litchi (Litchi chinensis Sonn.) production and quality criteria for exports with special reference to diseases and pests. International Conf. on Pest and Pesticide Management for Sustainable Agriculture, Kanpur.

Menzel, C.M. and Simpson, D.R. 1990. Effect of paclobutrazol on growth and flowering of lychee (Litchi chinesis). Australian J. Experimental Agri., 30:
131-137.

Mitra, S.K., Sanyal, D., Huang, H.B. and Menzel, C. 2001. Effect of cincturing and chemicals on flowering of litchi, Proceedings of the First International Symposium on litchi and longan, Guangzhou, China, 16-19 July 2000, Acta Hort., 558: 243-246.

Nagao, M.A., Hoa, E.B., Nishina, M.S. and Zee, F. 2000. December pruning of vegetative flushes affects flowering of 'Kaimana' lychee in Hawaii. $J$. Hawaiian Pacific Agric., 11: 17-21.

Oosthuizen, J.H., Froneman, I.J. and Roe, D.J. 1995. Long term effect of growth retardants and pruning on growth, yield and fruit quality of litchi (Litchi chinensis Sonn.) trees. J. South Afri. Soc. Hort. Sci., 5(2): 61-63.

Pandey, R.M. and Sharma, H.C. 1989. The Litchi (Litchi chinensis Sonn.) ICAR, New Delhi, pp. 54-61.

Pires, M.C. and Yamanishi, O.K. 2014. Girdling Combined with Paclobutrazol Boosted Yield of 'Bengal' Lychee in Brazil. Proc. XIIth IS on Plant Bioregulators in Fruit Production. Acta Hort. 1042, ISHS 2014.

Revathy, J. and Narasimham, P. 1997. Litchi (Litchi chinensis Sonn.) Fruit: influence of pre and post harvest factors on storage life and quality for export tradeacritica; appraisal. J. Food Sci. Tech., 34(1): 1-19.

Singh, D.K. 1996. Effect of paclobutrazol on growth and bearing mango cultivars. Ph.D. thesis, GBPUAT, Pantnagar, U.P.

\section{How to cite this article:}

Sonam Ongmu Bhutia, Aditi Guha Choudhury and Md. Abu Hasan. 2017. Paclobutrazol in Improving Productivity and Quality of Litchi. Int.J.Curr.Microbiol.App.Sci. 6(8): 1622-1629. doi: https://doi.org/10.20546/ijcmas.2017.608.195 